
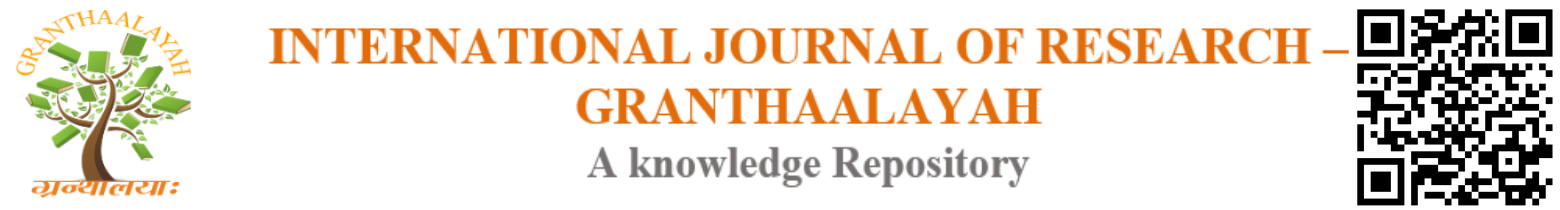

Management

\title{
GROWTH OF FINANCIAL DEVELOPMENT IN SUB SAHARAN AFRICAN (SSA) REGION THROUGH MIGRANT REMITTANCES
}

\author{
Nuruddeen Usman *1 \\ ${ }^{* 1}$ Central Bank of Nigeria, Nigeria
}

\begin{abstract}
This Paper investigates the impact of remittances on the financial development of countries in the sub-Saharan Africa using panel data analysis from 1985 to 2013. Several Literature has been written on the impact of remittance on growth and on poverty in sub-Saharan Africa however few have critically analysed the impact of remittances on financial development in the region. Using two definitions of financial development, the ratio of money supply to GDP (M2/GDP), and the ratio of domestic credit to GDP (DC/GDP), this paper finds that remittances have a positive effect of financial development. However, the size of the effect depends on definition of financial development that is used in the analysis.
\end{abstract}

Keywords: Remittances; Sub-Saharan Africa; Growth; Financial Development.

JEL Classification: F22, J61, 016

Cite This Article: Nuruddeen Usman. (2019). "GROWTH OF FINANCIAL DEVELOPMENT IN SUB SAHARAN AFRICAN (SSA) REGION THROUGH MIGRANT REMITTANCES." International Journal of Research - Granthaalayah, 7(3), 79-96. https://doi.org/10.29121/granthaalayah.v7.i3.2019.945.

\section{Introduction}

Remittances are transfers of money by international migrants back to their home countries. This is usually transferred between families or communities. Financial development refers to ways in which financial intuitions e.g. banks improve which encourages growth and reduction of poverty. Remittances from international migrants have played an important role as a source of external finance for developing countries. In some countries remittances are the largest source of finance after FDI and possibly aid. Remittances to developing countries are up by 3.5\% compared to 2012 . As at 2013, it was $\$ 404$ billion. Although sub-Saharan African (SSA) countries share of remittances is quite low at $4 \%$, there is proof that some of it is underreported due to the informal nature of some of these transactions. Looking at the SSA region, Dilip et al. (2014) gives data showing Nigeria was the largest recipient of remittances in sub-Saharan Africa (SSA) and the 5th in the world in 2013, receiving \$21 billion from international migrants. Moreover, Adams (2006), estimates remittance through informal channels could add at least " $50 \%$ to the globally" recorded 
flows. Remittance through informal channels sent to sub-Saharan Africa, was estimated to be between "45-65\% of formal flows" Gupta (2007). Remittances are also used as a source of foreign receipts. For example, in 2013, remittances were "equivalent to $22 \%$ of exports" receipts of petroleum received by Nigeria Dilip et al. (2014).

Table 1 below, shows the amount of remittances (inflows and outflows) between developing countries and the world. According to the World Bank, remittance inflows have increase from US\$ 131.5 billion in 2000 to US\$ 416 billion in 2009. The amount of remittances inflows worldwide more than doubled over this time period. The share amount of remittances being received by developing countries has also been increasing from 62\% in the year 2000 to $74 \%$ in year 2009. Table 2 shows how remittances have become a source of revenue for developing countries and how remittances are larger than aid going to developing countries.

Table 1: Global Remittances showing contrast between Developing countries and the rest of the world

\begin{tabular}{|l|l|l|l|l|l|l|l|l|l|}
\hline \multicolumn{1}{|c|}{ in USD billions } & $\mathbf{1 9 9 5}$ & $\mathbf{2 0 0 0}$ & $\mathbf{2 0 0 4}$ & $\mathbf{2 0 0 5}$ & $\mathbf{2 0 0 6}$ & $\mathbf{2 0 0 7}$ & $\mathbf{2 0 0 8}$ & $\mathbf{2 0 0 9}$ & $\mathbf{2 0 1 0 e}$ \\
\hline Inflow world & 101.3 & 131.5 & 237 & 274.9 & 317.9 & 385 & 443.2 & 416 & 440.1 \\
\hline $\begin{array}{l}\text { Inflow of remittance } \\
\text { flows developing } \\
\text { countries }\end{array}$ & 55.2 & 81.3 & 159.3 & 192.1 & 226.7 & 278.5 & 324.8 & 307.1 & 325.5 \\
\hline Outflow World & 97.5 & 108.5 & 168 & 185.3 & 213.7 & 255.2 & 295.7 & 282.5 & \\
\hline $\begin{array}{l}\text { Outflow developing } \\
\text { countries }\end{array}$ & 10.4 & 9.5 & 28.5 & 33 & 41 & 52.7 & 67.3 & 58.7 & \\
\hline
\end{tabular}

Source: (World Bank, 2011)

Table 2: Flows to developing countries showing increased contribution of remittances

\begin{tabular}{|l|l|l|l|l|l|l|l|l|}
\hline \multicolumn{1}{|c|}{ US \$ billions } & $\mathbf{1 9 9 5}$ & $\mathbf{2 0 0 0}$ & $\mathbf{2 0 0 4}$ & $\mathbf{2 0 0 5}$ & $\mathbf{2 0 0 6}$ & $\mathbf{2 0 0 7}$ & $\mathbf{2 0 0 8}$ & $\mathbf{2 0 0 9}$ \\
\hline FDI & 95 & 149 & 208 & 276 & 346 & 514 & 593 & 359 \\
\hline Remittances & 55 & 81 & 159 & 192 & 227 & 278 & 325 & 307 \\
\hline Overseas development assistance & 57 & 49 & 79 & 108 & 106 & 107 & 128 & 120 \\
\hline Portfolio debt and equity & 83 & 27 & 93 & 165 & 211 & 434 & 157 & 85 \\
\hline
\end{tabular}

Source: (World Bank, 2011)

Figure 1 equally shows the top recipient of remittances in the world as at 2010. The amount of remittances received by China and India is five times the size of the largest recipient of remittances in sub-Saharan Africa Nigeria, with US\$ 10 billion. Correspondingly, Figure 2 shows top 10 remittance recipient countries as a percentage of gross domestic product (GDP). Tajikistan leads the way with the highest share at $35 \%$ of GDP, whilst Lesotho the highest sub-Saharan country has remittances contributing $25 \%$ to the country's gross domestic product. Similarly, for the subSaharan African region, Nigeria leads the way with remittance inflows, from 1970-2014e, Nigeria has received US\$ 205,671million in remittance inflows into the country from the diaspora. The next four highest after Nigeria, are Senegal with US\$18,382 million, Lesotho US\$16,107 million, South Africa with US\$13,471 million and Kenya with US\$ 11,242 million. 


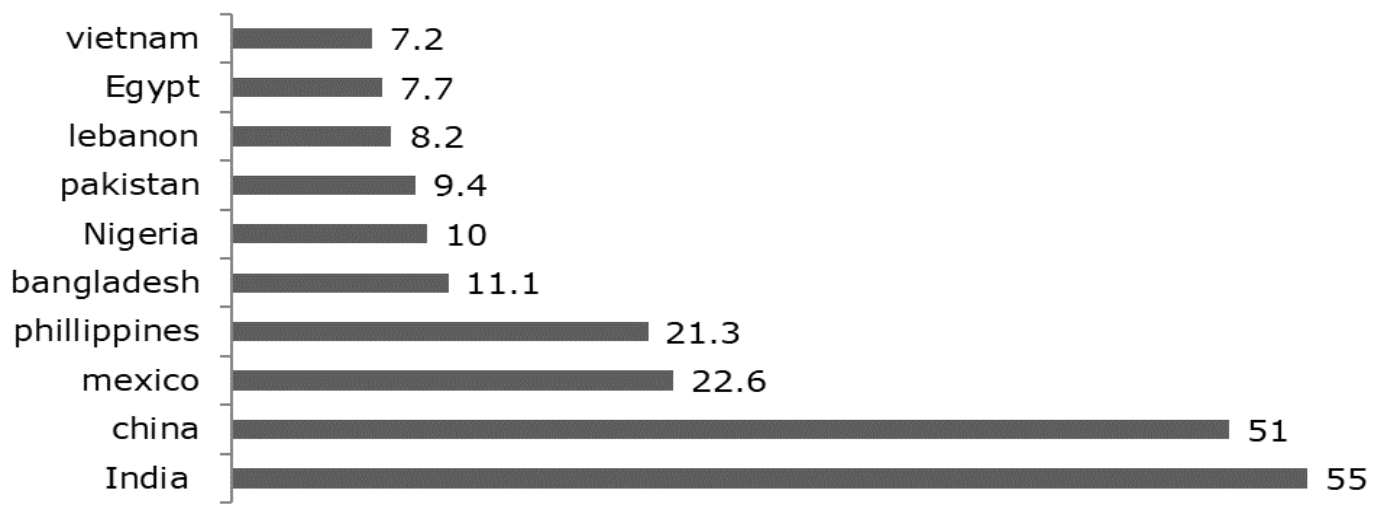

\section{Amount of remittances received in USD billion}

Figure 1: Top 10 recipients of global remittances in 2010 (World Bank, 2011).

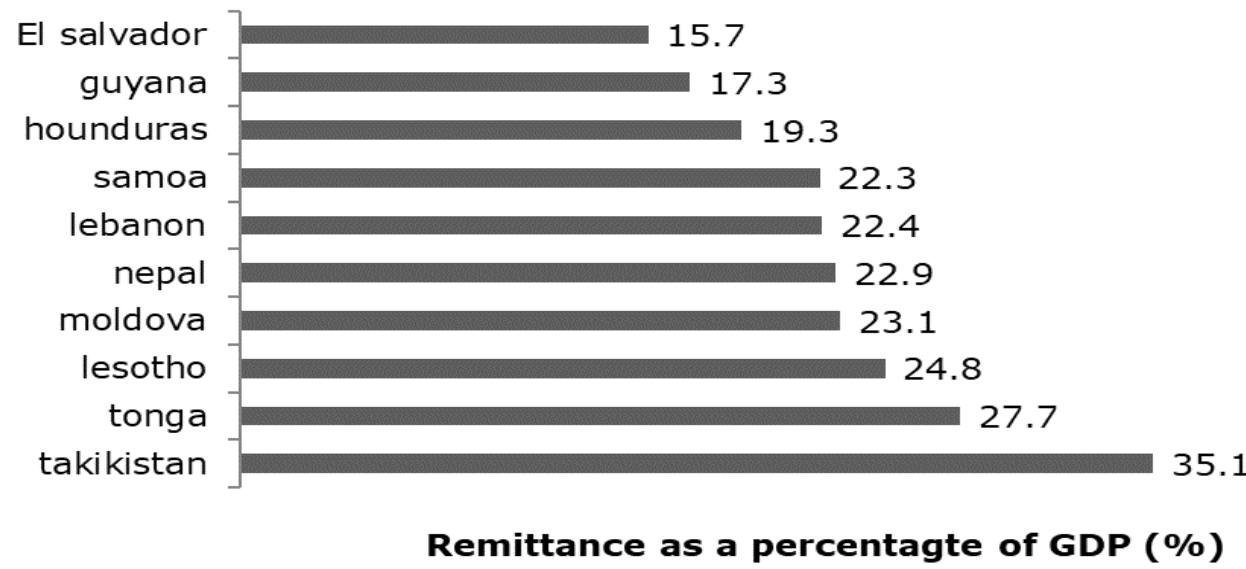

Figure 2: Top 10 countries share of remittances as a proportion of GDP in 2010 (World Bank, 2011)



Figure 3: Top 10 inflows for Sub-Saharan Countries between 1970 to 2014 (expected) in USD million 


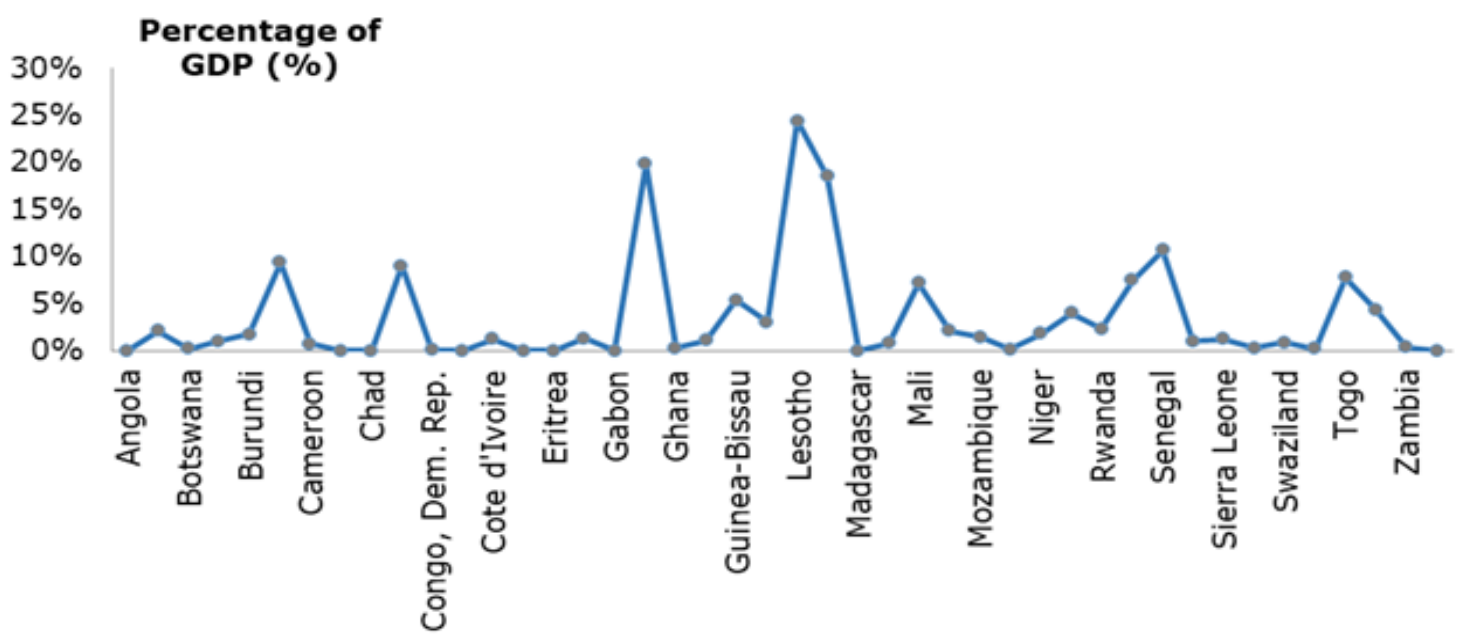

Figure 4: Remittances as a share of remittances to GDP in several sub-Saharan countries in 2013 (see note 2)

Consistent with what was observed in figure 2, figure 4 also shows the remittance share of gross domestic product (GDP) for several sub-Saharan African countries in 2013. The top five are Lesotho with $24 \%$ of GDP, Gambia with $20 \%$ of GDP, Senegal with $11 \%$ of GDP, Cape Verde with $9.3 \%$ of GDP and Comoros with $9.0 \%$ of GDP. This shows that smaller countries rely more heavily on remittances in Sub-Saharan Africa region and in showing how remittances are used as an alternate source to foreign direct investment as shown in figure 5. Figure 5 also highlights that while remittances might not be at the same level with foreign direct investment in sub-Saharan Africa, over the years, remittances have grown almost surpassing the level of FDI in 2005 when remittances where US $\$ 20$ billion and FDI was also US\$20 billion however, FDI has since increased to US $\$ 40$ billion in 2011 and remittances is at US\$29 billion in 2011 . This shows that whilst the level of foreign direct investment might fluctuate over time in sub-Saharan Africa the level of remittances remains stable and is increasing.

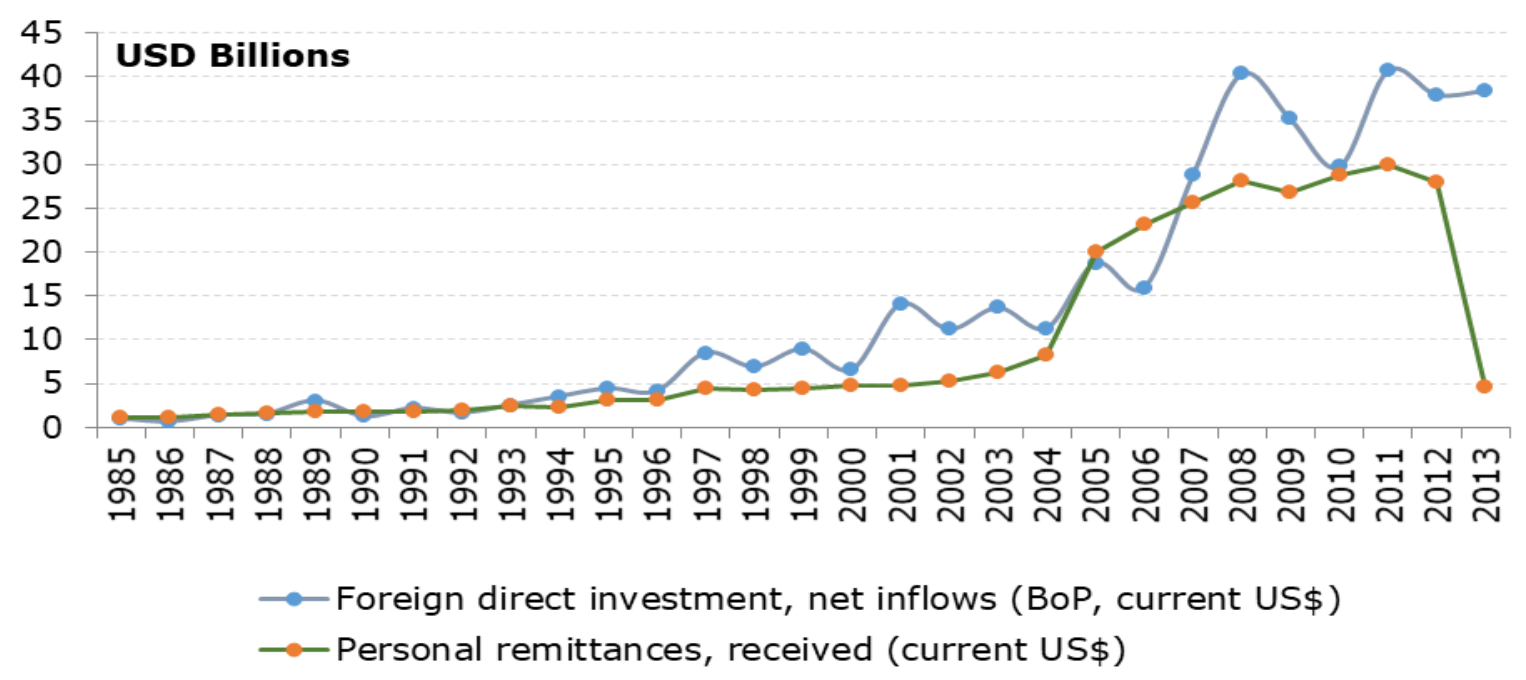

Figure 5: Total Resource inflow in the sub-Saharan Africa region from 1985-2011 
Figure 6 shows the amount of remittances received by sub-Saharan countries compared to the rest of the world. The amount of remittance transfers to sub-Saharan Africa is not that large when compared to the rest of the world, but has remained consistent overtime. In 2005 sub-Saharan African represented $7 \%$ of remittance transfers whilst in 2011 it was at $6 \%$ of world transfers. However, as stated earlier, due to high number informal flows for the region, the amount of transfers to the region might be highly understated.

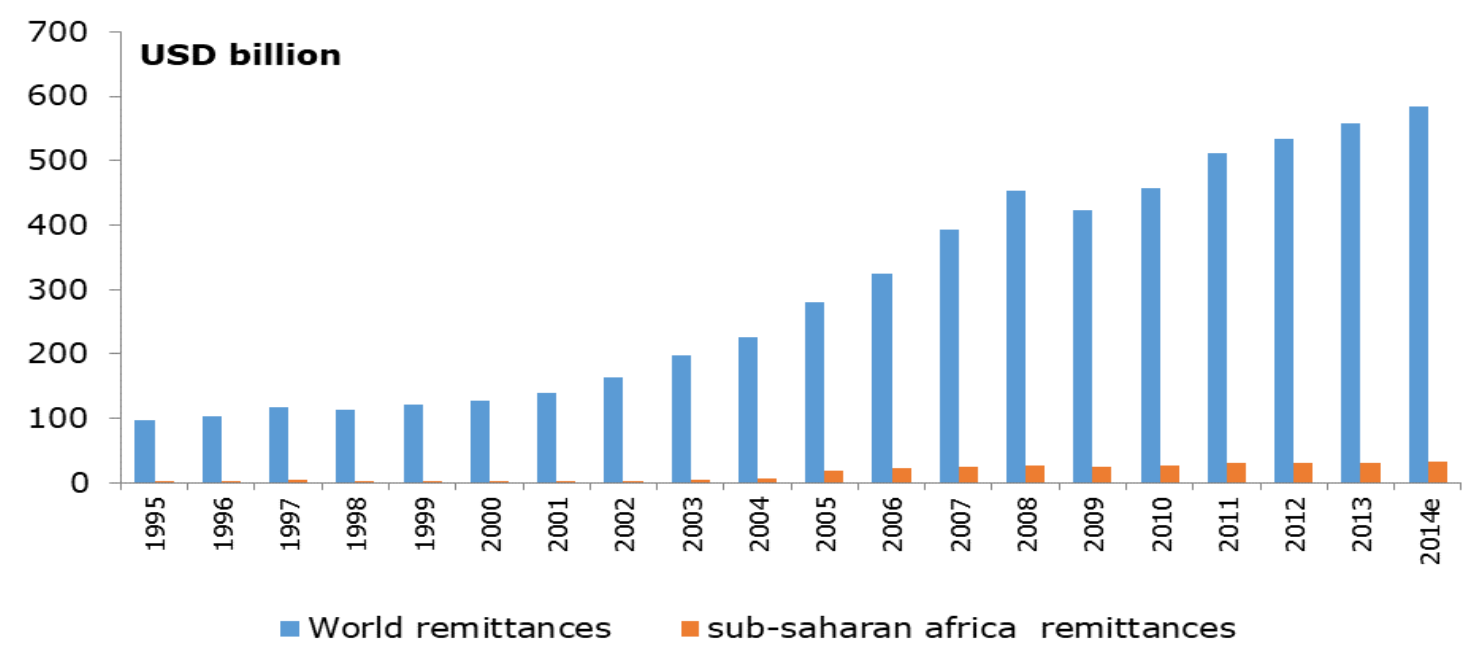

Figure 6: Amount of remittances received by sub-Saharan countries compared to the rest of the world

The diagrams above highlight how remittances have been a source of revenue for developing countries to carry out capital projects. This paper will discuss how remittances affect sub-Saharan region through financial institutions; review the trend remittances of to SSA and how they have grown over time. The first issue to be discussed is what the effect of remittances on financial development in the SSA region. Remittances are an additional source of income for the recipient households that are used to smooth consumption, increase household spending through the multiplier effect, and provide capital for investment. Using household survey data, Azam, et al. (2006) finds the "insurance and moral hazard of migration and remittances as a source of smoothing consumption".

Using data from the World Bank, this thesis will also review the impact of remittances on growth of financial development. Because transfer of remittances usually involve the use of formal financial services, remittances can be used by low-income household to access financial services. Aggarwal (2011), finds that remittances may affect the growth in financial development by recipients saving the flows, which increases the amount of funds available to banks to lend to the private sector. The influence remittances have on the growth of financial development depends on how households use remittances effectively. Well-functioning markets lower the cost of transfers of remittances, hence remittances might be pushed towards projects with high returns leading to higher growth. However, remittances might act as substitutes to financial markets by helping entrepreneurs bypass high lending cost to start projects and conversely perhaps prevent them from benefitting from the discipline that having a lender may bring. For sub-Saharan Africa, it is likely that remittances act as substitutes due to insufficient availability of formal financial services. There 
has been a lot of research on the impact of remittances. However the literature on the impact of remittances specifically on financial development is limited, particularly with respect to countries in the SSA region. For the past decade the SSA region has experienced strong GDP (gross domestic product) growth, this thesis will try to look at if growth in financial development occurred through remittances. Another reason to study the impact of remittances in SSA region is that Remittances have large benefits on African economies it tends to improve their credit worthiness particularly for external borrowing. Remittances are also included in the calculation of exports of countries. Higher remittances will likely improve debt to export ratio which will help lower borrowing costs required to finance infrastructural development. (Ratha, 2003) Shows that remittances tend to rise during times of economic hardship, which tends to smooth household consumption. (Yang, 2008) Shows Remittances are also a source for investment in education. This has an effect on productivity and economic growth.

Panel data analysis is carried out using data on remittances from year 1985 to 2013 to investigate the link between remittances and financial development in sub-Saharan Africa region. The focus variable will be the level of financial development, which will go by two definitions; the ratio of money supply to GDP (M2/GDP) and the ratio of domestic credit lent by banks to GDP (DC/GDP). The ratio of money supply to GDP (M2/GDP) measures the financial depth of financial institutions whilst the ratio of domestic credit relative to GDP (DC/GDP), helps to capture the amount of loans given out by private sector institutions. Whilst the impact of remittances on financial development in sub-Saharan Africa is unclear, the expectation is that remittances transferred through financial institutions can lead to recipients of remittances engaging more in the purchases of financial products. However, remittances could also not increase the amount of loans given to the private sector, as banks might be reluctant to provide loans or if remittance recipients do not store their remittances with financial institutions. It must be noted that whilst studying the impact of remittances on financial development in sub-Saharan Africa, a number of problems might arise due endogeneity bias of estimates as a result of reverse causality, measurement error and omitted variables bias. Additionally, balance of payments data on country remittances as described earlier does not capture remittances sent through informal routes such as non-banking institutions. A good example is the Hawala system, popular in the horn of Africa, where money is sent through informal routes. As a result the amount of remittances for a number of east African countries might be underreported, due use of the hawala system

The problem of reverse causality also arises due to greater financial development leading to increased remittances and or due to higher level of financial development causing the cost of sending remittances to countries to decrease which increases the flow of remittances. To try and address these concerns estimations are carried out to include country fixed effects and time effects and to help correct for the problem of endogeneity instrumental variable (IV) arising from reverse causation, omitted variable bias and measurement error instruments such as country level of unemployment are used, with the expectation that countries with higher levels of employment receive higher amount of remittances. Also, the annual Gross domestic product growth rate is also used as an instrument al variable.

The rest of the paper is structured as follows; section two provides a review of the existing and current work carried out on remittances and financial development. The next section, section three, provides a detailed look at the data being used to carry out this estimation and the models being 
used for certain regressions. Section four provides the results of estimation and analysis of certain variables of the regression carried out. The final section summarizes the dissertation, its findings and what it implications could mean for the countries of the sub-Saharan Africa region going forward.

\section{Literature Review}

Remittances are transfers of monies by migrants back to their country of origin from abroad to their families or communities. This is used for different things such as consumption needs, services or setting up businesses. Remittances are used for different purposes; Dean (2005) finds that remittances are used to pay for education of children which spurs human capital development. In this thesis financial development is referred to ways in which a country's financial system can be advanced to encourage growth in financial sector activities and reduce poverty. Similarly, Valpy (2006) describes financial development as "the establishment and expansion of institutions, instruments and markets that support this investment and growth process". A study by Petra et al (2013) finds that financial development is strongly associated with economic growth, also, Asli \& Ross, (2009) find that financial development encourages investment, this generates higher incomes for people hence reducing poverty and inequality.

The recorded flows of remittances are lower than the unofficial amount of transfers that take place through unrecorded flows as shown by Adams (2006). This finds that remittances that are not documented could add to as much as "half of flows of remittances globally". Furthermore, the subSaharan region (SSA) has highest unrecorded flows globally. An estimate by Gupta (2007), finds that it could be between "45-65\%" of remittance flows to the SSA region. Overall, literature exists showing the impact of remittances is beneficial to countries which receive them. However most of these studies are based on surveys such as Sonia et al. (2011) who carries out a survey on migration and remittances in selected SSA countries. Generally, most studies have focused on the impact of remittances on growth and human capital development. For example Gupta (2007) opines that remittances are countercyclical with economic growth i.e. "when a country's economies are performing poorly, migrants tend to increase the transfers of their remittances". This distinct feature makes remittances source for consumption smoothing for families in terms of hardship as enables families and communities to be able to meet consumption needs.

Literature exists on how remittances influence investment. Aggarwal (2011) finds that remittances may encourage investment in countries where they are received. This is based on remittances being transferred through banks as recipients might be tempted to open deposit accounts, bank will have more capital to lend out to the private sector, Funkhouser (1992) and Woodruff \& Zenteno (2004), find that increase in deposits linked to remittance flows have alleviated constraint of credit faced by developing counties. However, remittances could also discourage families and communities from engaging with financial service providers as most remittances are spent on consumption needs Quartey \& Blankson (2004). However, it could be argued that families look to remittances for credit rather than through facilities from local financial sector. Also, if recipients do not have confidence in financial systems in place they will not deposit their transfers with the financial institutions. This will mean fewer funds available for banks to be able to lend out to private investors. Banks could also play a role in not giving out credit from remittances to private sector investors as Manuel \& Rachel (2006) and Aggarwal (2011), point out that banks may refuse to 
lend to the public sector or may want to keep liquid assets in their possession rather than lending them out.

The relation between remittances, financial development and economic growth has a lot of literature on it with mixed results. Nevertheless; remittances are generally found to encourage the financial development. Paola \& Marta (2009) argue that one the one hand, “...lowering costs of conducting transactions may help direct remittances to projects that yield the highest return and therefore enhance growth rates of financial development", while on the other hand "remittances might also replace financial markets". In addition, Paola \& Marta (2009) suggest that without wellfunctioning markets, countries who receive large amount of remittances have growth in financial development and countries with systems that are efficient do not receive any significant impact to their growth by remittances.

Correspondingly, the relationship between remittances and economic growth in gross domestic product (GDP) is mixed. Several studies such as, Solimano (2003) which look at the relationship between remittances on growth in Andean countries find a positive relationship between growth and remittances. This is also endorsed by Faini (2002), using cross country data for analysis for a group of developing countries that remittances encourage growth. Also, an analysis of the Mexican economy by Adelman \& Taylor (1990), finds that "every dollar Mexican migrants send back home or bring back with them increases Mexico's GNP from anywhere between \$2.69 and \$3.17, depending on which household income group received the remittances". On the contrary, Chami et al. (2005) using analysis of selected developing countries find that "remittances diminish growth of selected developing countries, as the recipients of remittances will become financially dependent on immigrant workers" hence reducing the incentive to work, or possibly leaving employment. In spite of this, Spatafora (2005) finds there are "no links" which exist which exist to explain the impact of remittances on economic growth as it insignificant. Nonetheless, Catrinescu et al. (2008), argues that institutions have a role to play in ensuring long term growth as remittances will only generate long term growth if countries have the right type of economic policies and political systems Catrinescu et al. (2008). Also critics Chami, et al. (2005) work on immigration, as the literature failed to address problems associated with panel data which may have resulted coefficients being biased due to autocorrelation.

As majority of developing countries rely on aid or foreign direct investment (FDI) as a source of foreign exchange, remittances could provide a source foreign exchange. This is strongly supported by Bouhga-Hagbe (2004). Whilst looking at Morocco suggest that "remittances from migrants could be used as a source for development finance through foreign exchange earnings" and finds that remittances are used to finance construction projects. As source of foreign exchange, remittances help in improving countries external financial position as Bouhga-Hagbe (2004) shows, in Morocco foreign exchange through remittances have "cover the trade deficit and have contributed to the recent surpluses of the external current account". These large transfers of monies through remittances could lead to countries with developing economies having better export competitiveness through the appreciation of their currencies. However, IMF (2005) finds that that remittance do not suffer from "Dutch disease" which is centred towards natural resources as remittances have stable profiles and tend to increase during times of economic hardship. But while looking at the effect of remittances in Latin American and Caribbean countries using panel data Catalina \& Susan (2004) find that "doubling of transfers in the form of workers" remittances result 
in real exchange rate appreciation of about 22\%" for a group of 13 Latin American and Caribbean countries. But by and large, most studies have found remittances to be stable in profile.

Poverty is a problem which is faced by large part of the developing world; however there are limited literatures on the direct impact of remittances on poverty. Richardet al. (2005) Argues that "migration and remittances have a strong impact in the alleviation of poverty" the result is based on a group of 71 developing countries, the research took into account the endogeneity of migration and controlling factors such geographical location and poverty statistic. Richard, et al. (2005) puts foward that "on average, a 10\% increase in the share of international migrants in a country's population will lead to a $2.1 \%$ decline in the share of people living on less than $\$ 1.00$ per person per day" .similarly, the same was true for remittances as a " $10 \%$ increase in per capita official international remittances will lead, on average, to a 3.5\% decline in the share of people living in poverty" .These results suggest that if migrants keep sending transfers to their home countries, they can help reduce poverty. Using an analysis of El Salvador Campos \& Lardé de Palomo (2002) find that flows of remittances "reduced the amount of people in poverty by $4 \%$ ". However, Carling (2004) takes an opposing view and suggests that remittances may not benefit households with low skills as a result of costs arising from anti-immigrant policies such as those in major Organisation for Economic Co-operation and Development (OECD) countries which highly skilled migrants tend to favour. As a result Campos \& Lardé de Palomo (2002) paper skews the impact of remittances of recipient countries as it only increases per capita income while increasing the level of inequality within a society, as remittances will only be used by families of those who have emigrated in urban areas.

The relationship between remittances and financial development has not been well documented on the literature concerning remittances. A recent literature by Aggarwal (2011) Attempts to discuss the impact of remittances on financial development on developing countries over a period of time, using an analysis of several developing countries over time. This was based on the analysis that remittances might be channelled through financial systems and informal routes were not taken into account. Aggarwal (2011) found a "positive correlation between financial development and remittances" This was done whilst controlling for factors which affect financial development such openness of an economy, GDP size and inflation. At the same time, correcting for endogeneity which may occur in the data set due measurement error and omitted variable bias. Conversely, Gupta (2007) while estimating the impact of remittances on poverty and growth in 44 SSA countries finds that remittances promote growth in financial development, this after controlling for reverse causality between poverty, remittances and financial development.

The link between remittances and diaspora bonds is limited. Only Israel and India have established bond programs. Remittances could be used by governments to finance projects in the migrant's home country which become a source of investment for developing countries. Remittances through diaspora bonds could generate new investment source for SSA countries, Ratha et al. (2008) Argues that SSA countries could raise "between \$5-10billion" from remittances through diaspora bonds. Also Dilip \& Sonia (2011) finds that the cost of sending remittances to SSA region is about " $10 \%$ of the principal fee". This makes it one of the highest in the developing world, hence discouraging investment and high transaction costs between the migrants and their homeland. By encouraging the formation of diaspora bonds in African countries transaction costs can be bypassed. 
In conclusion, there has been a large number of literature on remittances mostly looking at growth, poverty and investment, whilst there has been little literature on the impact on remittances on financial development or in the SSA region in its entirety, probably as the share of world remittances to the SSA region might not be a great deal. But in the past few decades, the SSA region has experienced strong growth. Six of the world's fastest growing economies are from the region with growth averaging over $2 \%$ in the past decade. According to the World Bank, growth is expected to remain strong and robust. This thesis will attempt to look at if the change in growth fortunes for the region corresponds with growth in financial development over recent years through the use of remittances.

\section{Methodology}

\section{Data}

In this study a panel data analysis is used to study the effect of migrant remittances through financial development. Using data from 44 sub-Saharan African countries between the years 1985 to 2013. The baseline panel estimation carefully shadows the paper by Aggarwal, Demirguc-Kunt and Peria (2006)

The regression will include independent variables such as:

- The size of a country's economy which is captured by the variable, gross domestic product GDP (current US\$)

- The level of openness in a country is captured by the percentage of the sum of exports and imports relative to GDP

- The annual level of inflation which is captured by the consumer price index

- As a measure of productivity for different countries, per capita GDP (current US\$)

- The countries exchange rates relative to the USA (united states of America) Dollar, which is calculated in an annual basis based on monthly averages in a country

- The country specific level of foreign direct investment

- The dependent variable will be financial development; this is captured by the ratio of money supply to GDP and also the ratio of domestic credit to GDP.

All data in this regression analysis is in US dollars and were obtained from the World Bank development indicators report.

\section{Model Specification}

The aim of the model is to test the impact of remittances on financial development in the sub Saharan African (SSA) region, using a linear regression analysis of the form:

$$
\operatorname{logfindev}_{i t}=\alpha+\delta_{1} \operatorname{logrem}_{-i t}+\delta_{2} X_{i t}+\varepsilon_{i t}
$$

Where:

LOGFINDEV is the log of financial development in country (i) at time (t), while Log (remit) is the independent variable showing the log of remittance inflows in country (i) at time (t).

The parameter $X$ captures the country specific effect and $\varepsilon_{-}$it is the error term. 
The dependent variable in equation (1) (logfindev) has been defined in this model by both the ratio of money supply to gross domestic product M2/GDP and the level of domestic credit relative to Gross domestic product DC/GDP.

To test for the effectiveness in the model, the variable $\mathrm{X}$ is defined as a set of control variables; 『 $\delta_{2}$ is a vector of the coefficients on the variables in X; $\delta_{1}$ is the estimated coefficient of logremitt; and $\varepsilon$ is an error term. This comes with the expectation that, $\delta_{1}>0$.

Using ordinary least square estimation we specify the following broader equation:

$\operatorname{logfindev}_{i t}=\alpha+\lambda_{1} \operatorname{logrem}_{-i t}+\lambda_{2} \operatorname{logper}_{-i t}+\lambda_{3} \operatorname{loggdp}_{-i t}+\lambda_{4} \operatorname{logop}_{-} i t+\lambda_{5} \operatorname{loginf}_{-} i t+$ $\Lambda_{6} \log e x_{-i t}+\Lambda_{7} \log f d i_{i t}+\varepsilon_{i t}$

Where:

LOGFINDEV is the log of financial development, (logrem) is the log of remittances, (logper) is the log of gross domestic product per capita, (logGDP) is the log of gross domestic product, (logop) is the log of degree of opness, (loginf) is the log of the level of inflation, (logex) is the log of the country's exchange rate, (logfdi) is the log of the level of foreign direct investment. The parameters to be estimated are $\alpha$ and $\lambda_{1}$, the error term is represented $\varepsilon$ it.

Table 3 below shows the summary statistics of the variables being estimated in the regression analysis, the table indicates there is a lot of heterogeneity that exist between different countries. To check for the for the correlation matrix and how well certain variables might give an insight into the result of the estimation, table 4 gives the correlation matrix showing expectations of the analysis.

Table 3: Variables derived from regression analysis

\begin{tabular}{|l|l|l|l|l|l|}
\hline \multicolumn{1}{|c|}{ Variable } & Observations & \multicolumn{1}{c|}{ Mean } & Standard Deviation & Minimum & Maximum \\
\hline Log (remittances) & 861 & 3.812426 & 1.817661 & 0 & 9.947026 \\
\hline Log (exchange rate) & 1266 & 3.893246 & 3.828703 & -22.51778 & 9.855788 \\
\hline Log (inflation) & 1085 & 2.154949 & 1.36044 & -4.601903 & 10.19488 \\
\hline Log (GDP & 1250 & 21.94132 & 1.501423 & 17.94456 & 26.98056 \\
\hline Log (per capita GDP) & 1250 & 6.416764 & 1.103143 & 4.171462 & 10.06321 \\
\hline Log (DC/GDP) & 1121 & 3.064859 & 0.9398696 & -1.561454 & 5.766879 \\
\hline Log (openness) & 1213 & 4.184491 & 0.5144583 & 2.37475 & 6.27615 \\
\hline Log (M2/GDP) & 1187 & 3.210284 & 0.5965689 & -0.1855873 & 5.020908 \\
\hline Log (FDI) & 1120 & 0.3892362 & 1.87413 & -13.55186 & 5.086508 \\
\hline
\end{tabular}

Table 1: Correlation matrix derived

\begin{tabular}{|l|l|l|l|l|l|l|l|l|l|}
\hline & Inrem_ & Inex_ & \multicolumn{1}{|l}{ Ininf } & lnGDP & Inper & Indc & Inop & Inm2 & Infdi \\
\hline lnrem_ & 1.00000 & -- & -- & -- & -- & -- & -- & -- & -- \\
\hline lnex & 0.0184 & 1.0000 & -- & -- & -- & -- & -- & -- & -- \\
\hline lninf & -0.1953 & -0.2523 & 1.0000 & -- & -- & -- & -- & -- & -- \\
\hline lnGDP & 0.4941 & -0.162 & 0.0219 & 1.0000 & -- & -- & -- & -- & -- \\
\hline lnper & 0.1946 & -0.2556 & -0.1251 & 0.2668 & 1.0000 & -- & -- & -- & -- \\
\hline
\end{tabular}


DOI: $10.5281 /$ zenodo.2619363

\begin{tabular}{|l|l|l|l|l|l|l|l|l|l|}
\hline Indc & 0.1071 & -0.283 & -0.0625 & 0.1417 & 0.3916 & 1.0000 & -- & -- & -- \\
\hline $\operatorname{lnop}$ & 0.1202 & -0.2399 & 0.0424 & -0.2185 & 0.4661 & 0.1702 & 1.0000 & -- & -- \\
\hline $\ln 2$ & 0.2699 & -0.2863 & -0.1599 & 0.0417 & 0.5537 & 0.6815 & 0.44 & 1.0000 & -- \\
\hline $\operatorname{lnfdi}$ & 0.1407 & 0.0158 & 0.046 & -0.0437 & 0.2226 & -0.029 & 0.499 & 0.1984 & 1.0000 \\
\hline
\end{tabular}

\section{Indicators of Financial Sector Development}

Two indicators are used in this dissertation to ascertain the impact of remittances on financial development in sub-Saharan Africa. They are known as the ratio of money supply (figure 7) to gross domestic product (GDP) which specifies the depth of institutions and the ratio of domestic credit (figure 8) to GDP which specifies the amount of loans or loanable funds given to the private sector by financial institutions. The variable remittance captures the transfers of monies between Diasporas and their native country for more than a year. All the data sets used in this analysis are obtained from the World Bank world development indicators website 2013.

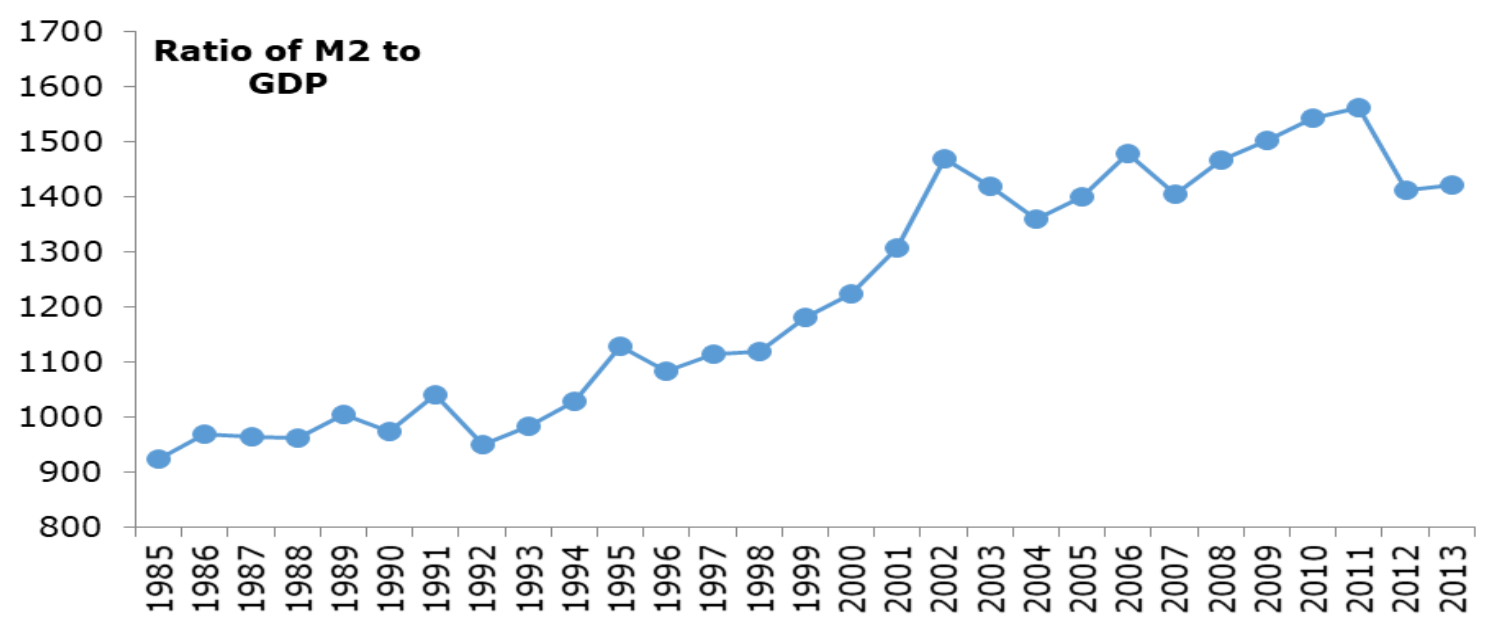

Figure 7: Ratio of money supply to GDP in sub-Saharan African countries from 1985 to year 2013.

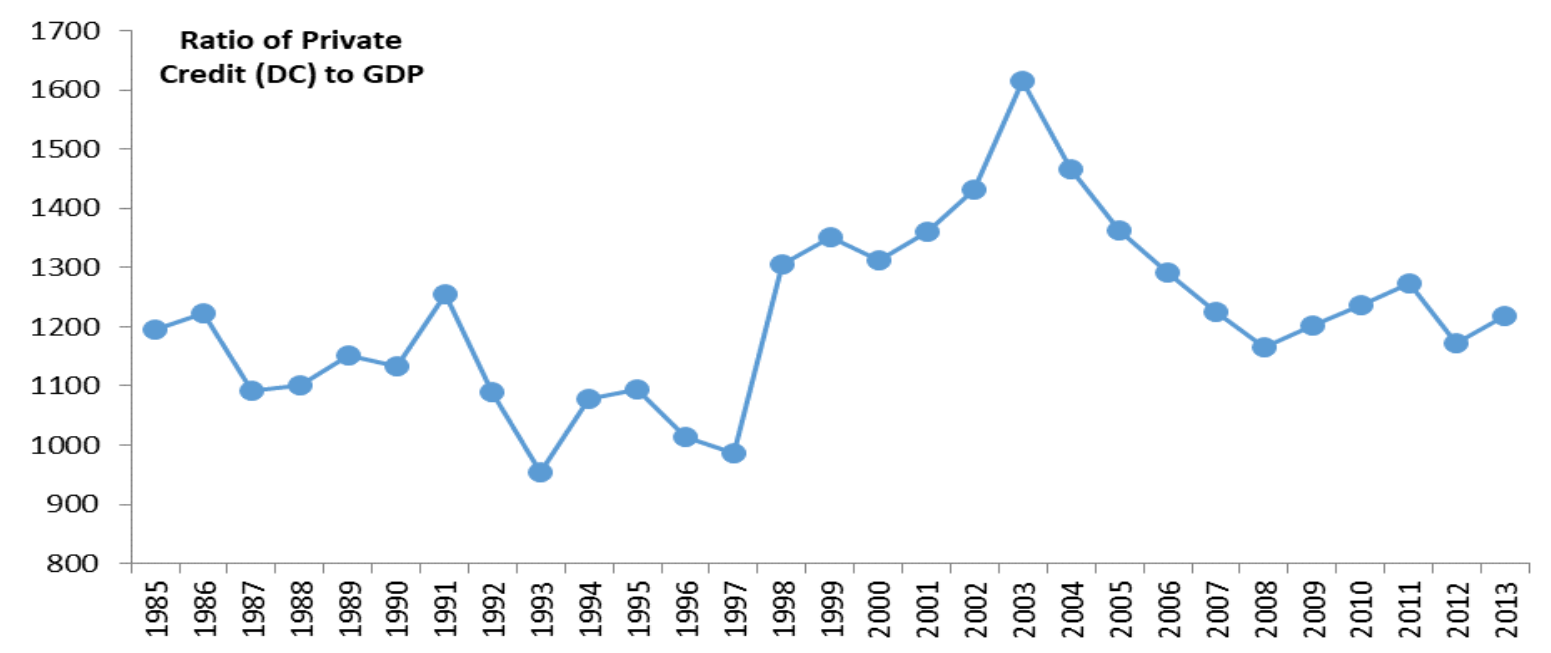

Figure 8: Ratio of private credit to GDP in sub-Saharan Africa countries from 1985 to 2013. 


\section{Control Variables in Regression Analysis}

In the regression, there are 7 independent variables being estimated, as equation (1) shows X refers to set of variables that impact financial development. In the log of each variable is carried out. For example, during an analysis studying the impact of inflation and financial development, Bittencourt (2011) found that inflation has influences financial development of countries financial sectors.

\section{Results and Findings}

The table 5 below reports estimates of equation (2) with country fixed effects being columns (12) and random effects being columns (3-4) for the share of money supply to GDP (M2/GDP) and domestic credit to GDP (DC/GDP). In the regression factors that are controlled are the log of per capita income, $\log$ of GDP, log of openness, log of inflation, log of exchange rate and the log of the country amount of foreign direct investment.

Across all estimates, the coefficient of variable remittances is positively related to the level of financial development, but the coefficients are larger for estimates which have money supply ratio to GDP (M2/GDP) as a dependent variable that for domestic credit to GDP (DC/GDP) regressions. All things being equal and controlling for fixed effects, a one percentage point increase in remittances enhances financial development in sub-Saharan Africa by 0.027 and 0.067 , when me measure the later by money supply to GDP and the ratio of credits to GDP respectively.

Also, in line with expectations the results reveal that both inflation and exchange rates exert negative effects on financial development. However, the measure for productivity (GDP per capita) appears to have a strong relationship as to how financial development takes place, showing that increases in productivity, enhances financial development.

Surprisingly, the size of the economy appears to have taken a negative coefficient regardless of the definition of financial development involved, the only exception is when controlling for fixed effects and the dependent variable is the level of domestic credit to GDP. Column 1 and 2 represents country fixed effects and $3 \& 4$ random effects.

Table 5: Estimation with Country Fixed Effects

\begin{tabular}{|l|l|l|l|l|}
\hline & \multicolumn{1}{|c|}{ (fixed) } & \multicolumn{1}{c|}{ (fixed) } & \multicolumn{1}{c|}{ (random) } & \multicolumn{1}{c|}{ (random) } \\
\hline & \multicolumn{1}{c|}{ Deposits } & \multicolumn{1}{c|}{ M2 } & \multicolumn{1}{c|}{ M2 } & \multicolumn{1}{c|}{ Deposits } \\
\hline Log (remittances) & 0.027 & $0.0678^{* * *}$ & $0.0771^{* * *}$ & 0.0274 \\
\hline & -1.13 & -5.83 & -6.9 & -1.21 \\
\hline Log (per capita GDP) & $0.310^{* * *}$ & $0.202^{* * *}$ & $0.223^{* * * *}$ & $0.304^{* * *}$ \\
\hline & -7.09 & -9.54 & -11.08 & -7.44 \\
\hline Log (GDP) & 0.000484 & $-0.0772^{* * *}$ & $-0.0710^{* * *}$ & -0.0074 \\
\hline & -0.02 & $(-4.90)$ & $(-4.77)$ & $(-0.25)$ \\
\hline Log (openness) & 0.0281 & 0.102 & 0.0968 & 0.0132 \\
\hline & -0.25 & -1.84 & -1.78 & -0.12 \\
\hline Log (inflation) & -0.0386 & $-0.0547^{* * *}$ & $-0.0498^{* *}$ & -0.0443 \\
\hline & $(-1.18)$ & $(-3.36)$ & $(-3.24)$ & $(-1.44)$ \\
\hline
\end{tabular}


DOI: 10.5281/zenodo.2619363

\begin{tabular}{|l|l|l|l|l|}
\hline Log (exchange rate) & $-0.0640 * * *$ & $-0.0495 * * *$ & $-0.0421 * * *$ & $-0.0734 * * *$ \\
\hline & $(-3.97)$ & $(-6.23)$ & $(-5.98)$ & $(-5.17)$ \\
\hline Log (FDI) & $-0.0625 *$ & -0.00925 & 0.00302 & $-0.0658 * *$ \\
\hline & $(-2.27)$ & $(-0.68)$ & -0.24 & $(-2.62)$ \\
\hline constant & 1.22 & $3.338 * * *$ & $3.005 * * *$ & 1.552 \\
\hline Number of observations & -1.32 & -7.26 & -7.1 & -1.84 \\
\hline R2 & 637 & 672 & 672 & 637 \\
\hline & 0.194 & 0.377 & 0.41 & 0.205 \\
\hline
\end{tabular}

t statistics in parentheses $* \mathrm{p}<0.05, * * \mathrm{p}<0.01, * * * \mathrm{p}<0.001$ used to signify level of significant t statistics in parentheses $* \mathrm{p}<0.05, * * \mathrm{p}<0.01, * * * \mathrm{p}<0.001$ used to signify level of significant

Table 6: Estimation with Country and Time Effects

\begin{tabular}{|l|l|l|l|l|}
\hline & (random) & \multicolumn{1}{|c|}{ (fixed) } & (random) & \multicolumn{1}{c|}{ (fixed) } \\
\hline & Deposits & Deposits & \multicolumn{1}{|c|}{ M2 } & \multicolumn{1}{|c|}{ M2 } \\
\hline Log (remittances) & 0.00851 & 0.00506 & 0.0177 & 0.00682 \\
\hline & -0.37 & -0.21 & -1.71 & -0.65 \\
\hline $\log$ (per capita GDP) & 0.0853 & 0.161 & 0.0903 & $-0.300^{* *}$ \\
\hline & -0.92 & -0.64 & -1.83 & $(-2.71)$ \\
\hline $\log$ (GDP) & -0.0302 & -0.0727 & 0.0668 & $0.397 * * *$ \\
\hline & $(-0.41)$ & $(-0.35)$ & -1.67 & -4.4 \\
\hline $\log$ (openness) & $0.381^{* * *}$ & $0.449 * * *$ & $0.403^{* * *}$ & $0.382^{* * *}$ \\
\hline & -3.7 & -3.99 & -8.62 & -7.75 \\
\hline Log (inflation) & -0.0363 & -0.0308 & $-0.0265^{* *}$ & $-0.0231^{*}$ \\
\hline & $(-1.66)$ & $(-1.39)$ & $(-2.71)$ & $(-2.39)$ \\
\hline Log (exchange rate) & $-0.104 * * *$ & $-0.118^{* *}$ & $-0.0420^{* *}$ & $-0.0596^{* * *}$ \\
\hline & $(-3.62)$ & $(-2.97)$ & $(-3.02)$ & $(-3.43)$ \\
\hline Log (FDI) & -0.00287 & -0.0021 & $0.0348^{* * * *}$ & $0.0282^{* *}$ \\
\hline & $(-0.15)$ & $(-0.10)$ & -4.08 & -3.27 \\
\hline Constant & 2.054 & 2.331 & -0.303 & $-4.936^{* * *}$ \\
\hline & -1.6 & -0.8 & $(-0.47)$ & $(-3.87)$ \\
\hline Number of observations & 637 & 637 & 672 & 672 \\
\hline R2 & 0.123 & 0.037 & 0.303 & 0.349 \\
\hline
\end{tabular}

$\mathrm{t}$ statistics in parentheses $* \mathrm{p}<0.05, * * \mathrm{p}<0.01, * * * \mathrm{p}<0.001$ used to signify level of significance

As expected, with country and time effects in table 6 above shows, the effect of financial development is determined by productivity (per capita GDP) and country level of income in sub Saharan Africa, but it is negatively affected by inflation and the country exchange rate also is negative. While the impact of foreign direct investment (FDI) is inconclusive, as the it has a negative effect when it comes to deposits but a positive effect when it comes to using ratio of money supply as measure financial development. The country level of Gross domestic product does not have a consistent effect, thus showing that, not only do remittances increase the amount of financial intermediaries available to the public and the level of intermediation, remittances 
helped in transferring loanable funds to private sector to carry out projects during the period under consideration in this analysis

Form table 5 and table 6 , the finding are that remittances always have a positive relationship with financial development with any indicator of financial development, the size of the economy in subSaharan Africa seems to be negligent to determining the level of financial development. But while the level of productivity in an economy significantly affects financial development in the 44 subSaharan countries, the magnitude and effect is weak. The effects of FDI is inconclusive.

However, these estimates in table 5 and 6 can be biased due endogeneity. As countries with better levels of remittance transfers have positive effects on financial institutions. To try and correct for the problem endogeneity, instruments are used. An instrumental variable is a variable used when correlation between the independent variable and the error term is suspected.

Table 7: Estimation With Instrumental Variables

\begin{tabular}{|c|c|c|c|c|c|c|c|c|}
\hline & (1) & (2) & (3) & (4) & (5) & (6) & (7) & (8) \\
\hline & deposit & M2 & Deposit & M2 & Deposit & M2 & Deposit & M2 \\
\hline \multirow{2}{*}{$\begin{array}{l}\text { Log } \\
\text { (remittances) }\end{array}$} & 0.251 & 0.295 & 0.0935 & 0.582 & 0.208 & -0.0304 & 0.324 & -0.0806 \\
\hline & $(-0.58)$ & -0.95 & -0.21 & -0.99 & -0.57 & $(-0.27)$ & -0.58 & $(-0.61)$ \\
\hline \multirow{2}{*}{$\begin{array}{l}\text { Log (per } \\
\text { capita GDP) }\end{array}$} & -0.723 & -0.304 & -0.0921 & 0.0739 & $0.303^{* *}$ & $0.161 * * *$ & $0.307 * * *$ & $0.163 * * *$ \\
\hline & $(-1.01)$ & $(-0.56)$ & $(-0.62)$ & -0.42 & -3.1 & -3.81 & -3.56 & -3.67 \\
\hline \multirow[t]{2}{*}{$\log (\mathrm{GDP})$} & 0.856 & 0.127 & 0.0214 & -0.45 & -0.0921 & 0.6 & -0.168 & 0.0448 \\
\hline & $\begin{array}{l}-0.89 \\
\end{array}$ & -0.17 & -0.05 & $(-0.70)$ & $(-0.35)$ & -0.01 & $(-0.42)$ & -0.47 \\
\hline \multirow{2}{*}{$\begin{array}{l}\text { Log } \\
\text { (openness) }\end{array}$} & $0.774 * *$ & 0.182 & 0.603 & 0.00846 & -0.138 & 0.187 & -0.239 & 0.258 \\
\hline & -2.78 & -0.98 & -1.7 & -0.02 & $(-0.36)$ & -1.2 & $(-0.43)$ & -1.42 \\
\hline \multirow{2}{*}{$\begin{array}{l}\log \\
\text { (inflation) }\end{array}$} & -0.0109 & -0.019 & -0.0438 & -0.0396 & -0.00444 & -0.0844 & 0.0235 & $-0.100 *$ \\
\hline & $(-0.25)$ & $(-0.64)$ & $(-1.24)$ & $(-0.89)$ & $(-0.04)$ & $(-1.92)$ & -0.14 & $(-2.04)$ \\
\hline \multirow{3}{*}{$\begin{array}{l}\text { Log } \\
\text { (exchange } \\
\text { rate) }\end{array}$} & 0.0745 & $\begin{array}{l}-0.0608 \\
\end{array}$ & 0.00291 & -0.104 & & & $-0.0945^{*}$ & \\
\hline & & & & & & & & \\
\hline & -0.91 & $(-1.18)$ & -0.05 & $(-0.90)$ & $(-3.20)$ & $(-5.80)$ & $(-2.34)$ & $(-4.81)$ \\
\hline \multirow{2}{*}{$\log (\mathrm{FDI})$} & 0.00348 & 0.00119 & -0.0265 & -0.0243 & $-0.102^{*}$ & -0.018 & -0.108 & -0.00221 \\
\hline & -0.07 & -0.04 & $(-0.46)$ & $(-0.37)$ & $(-2.18)$ & $(-0.90)$ & $(-1.41)$ & $(-0.10)$ \\
\hline \multirow[t]{2}{*}{ constant } & -14.16 & 0.702 & 0.211 & 11.15 & 3.298 & 2.021 & 4.888 & 0.91 \\
\hline & $(-0.84)$ & -0.06 & -0.02 & -0.8 & -0.62 & -1.19 & -0.58 & -0.44 \\
\hline $\mathrm{N}$ & 483 & 509 & 483 & 509 & 483 & 509 & 483 & 509 \\
\hline $\mathrm{R}$ squared & 0.198 & 0.145 & 0.221 & 0.1757 & 0.1682 & 0.2888 & 0.1262 & 0.2085 \\
\hline
\end{tabular}

$\mathrm{t}$ statistics in parentheses $* \mathrm{p}<0.05, * * \mathrm{p}<0.01, * * * \mathrm{p}<0.001$ used to signify level of significance

Source: Authors computation 
Using instruments such as country level of unemployment and country annual growth rate, table 7 shows the panel estimation for the instrumental variables. Where columns (1) to (4) capture the country and time effect and columns (5) to (8) capture the time effects. The instrumented variable remittances comes in with a positive value than previously estimated in table 1 and table 2 while the impact of inflation, trade openness and foreign direct investment (FDI) are consistent with table 1 and 2 however there appears to be differences for productivity (per capita GDP) across estimations. The instruments appear to be weak, however considering it a smaller sample than Aggarwal et al (2006) it works well for a larger number of developing countries.

Looking at the impact of remittances on financial development, the regression analysis without the instrumental variable gives a positive sign with regards to both the ratio of money supply to GDP and the level of domestic credit relative to GDP. The coefficients for the instrumental variable appear to be significantly larger than those obtained in previous estimations. These estimations and results carried out ascertain that the positive relationship between remittances and financial development in sub-Saharan region is not due endogeneity bias in estimates.

\section{Conclusions and Recommendations}

Remittances have been increasing steadily overtime and have become an important source of revenue for developing countries to use to finance their budgets as they are countercyclical and increase during times of hardship. Remittances unlike foreign direct investment are a strong and stable source of external revenue. Whilst the relationship between remittances and financial development was discussed in this dissertation, the impact of remittances has far reaching implications with regards to poverty and access to educational opportunities. This has been extensively explored. As a region with that suffers from low amount of foreign direct investment compared to the rest of the world, the analysis of remittances on sub-Saharan countries was intended to show that even in places where world remittance transfers are as low as 5\%, remittances have a positive relationship with financial development.

The analysis carried out examined baseline panel estimation for 29 years between 1985 and 2013. Financial development was defined as both the ratio of money supply to GDP and the ratio of domestic credit to GDP. While carrying out the estimation and controlling for fixed country and time effects, the results indicated that remittances positively affect financial development in subSaharan Africa. To strengthen the results due to the problem of endogeneity, instrumental variables were used in the estimation to make sure estimates were robust. The findings with the instrumental variable also showed that remittances had a positive impact financial development in sub-Saharan Africa region. The results of analysis also indicate that remittances are used for more consumption purposes in sub-Saharan Africa than for creating or starting businesses. Furthermore, the analysis shows that the degree of openness, level of exchange rate and level of inflation all appear to have negative effects on financial development in Sub-Saharan Africa. Overall this dissertation find remittances can have positive effects for financial development and they should be harnessed more as a source of revenue for development and through improving of remittances formal and informal providers and reducing transfer cost of sending money to countries in sub-Saharan Africa countries. In harnessing the potential of remittances, more financial institutions of countries will be able to loan more funds out to carry out development projects. 


\section{References}

[1] Adams, R. (2006). Remittances and poverty in Ghana. Washington, DC: World Bank Policy Research Paper 3838.

[2] Adelman, I., \& Taylo, J. (1990). Is Structural Adjustment with a Human Face possible? the case of Mexico. Journal of Development Studies, 26(3), 387-407.

[3] Aggarwal, R. A.-K. (2011). Do remittances promote financial development? Journal of Development Economics (96.2), 255-264.

[4] Asli, D.-K., \& Ross, R. L. (2009). Finance and Inequality: Theory and Evidence. Massachusetts: National Bureau of Economic Research.

[5] Azam, Jean-Paul, \& Gubert, F. (2006). Migrants' remittances and the household in Africa: a review of evidence. Journal of African Economies, 15(suppl 2), 426-462.

[6] Bouhga-Hagbe, J. (2004). A theory of workers remittance with an application to morroco. Washington: IMF.

[7] Campos, R., \& Lardé de Palomo , A. (2002). “Invirtamos en Educación para Desafiar el Crecimiento Económico y la Pobreza. Fundación Salvadoreña para el Desarrollo.

[8] Carling, O. J. (2004). Emigration, return, and development in Cape Verde: The impact of closing border. Population, Society, and Place.

[9] Catalina, A.-D., \& Susan, S. P. (2004). Workers' Remittances and the Real Exchange Rate:A Paradox of Gifts. World Development, 32(8), 1407-1417.

[10] Catrinescu, N., Miguel, L.-L., \& Bryce, B. Q. (2008). Remittances, Institutions, and Economic Growth. World Development, 37, 81-92.

[11] Chami, R., Fullenkamp, C., \& Jahjah, S. (2005). Are Immigrant Remittance Flows a source for capital development. IMF Staff Papers.

[12] Dean, Y. (2005). International Migration, Human Capital, and Entrepreneurship: Evidence from Philippine Migrants' Exchange Rate Shocks. Michigan: National Bureau of Economic Research.

[13] Dilip, R., \& Sonia, P. (2011). Harnessing Diasporas. IMF.

[14] Dilip, R., Supriyo, D., Ervin, D., Christiani, E.-Z., Sonia, P., Hanspeter, W., et al. (2014). Migration and development brief: Migration and Remittances: Recent Developments and Outlook. Washington: World Bank.

[15] Faini, R. (2002). Development, Trade, and Migration. Revue d'Économie et du Développement, 85-116.

[16] Funkhouser, E. (1992). Migration from Nicaragua: Some Recent Evidence. World- Development, 20(8), 1209-1218.

[17] Gupta, S. C. (2007). Impact of remittances on poverty and financial development in Sub-Saharan Africa. nternational Monetary Fund.

[18] IMF. (2005). Two current issues facing developing countries: Workers remittances and economic development.. World Economic Outlook.

[19] Kireyev, A. (2006). The Macroeconomics of Remittances:The Case of Tajikistan. washinton: International Monetary Fund.

[20] Manuel, O., \& Rachel, F. (2006). Leveraging effrots on remittances and financial intermidiation. Inter-American Development Bank.

[21] Misati, R., \& Nyamongo, E. (2011). Financial development and private investment in Sub-Saharan Africa. Journal of economics and buisness, 63(2), 139-151.

[22] Paola, P., \& Marta, M.-A. (2009). Remittances, financial development, and growth. journal of development economics, 90, 144-152.

[23] Petra, V., Tomas, H., \& Roman, H. (2013). Financial Development and Economic Growth:A MetaAnalysis. michigan: William Davidson Institute.

[24] Quartey, P., \& Blankson, T. (2004). Do migrant remittances minimize the effect of macro-volatility on the poor in Ghana? 
[25] Rapoport, H., \& Docquier, F. (2006). The Economics of Migrants' Remittances. Handbook of the Economics of, Volume 2, 1135-1199.

[26] Ratha, D. (2003). Worker Remittances: An Important and Stable Source of External Development Finance, Global Development Finance. world bank.

[27] Ratha, D., S, M., \& S, P. (2008). Beyond aid: New sources and innovative mechanisms for financing development in sub-Saharan Africa. Washington: World Bank.

[28] Richard, H., Adams, J., \& John, P. (2005). Do International Migration and Remittances Reduce Poverty in Developing Countries? World Development, 33(10), 1645-1669.

[29] Solimano, A. (2003). Workers Remittances to the Andean Region: Mechanisms, Costs and Development impact.

[30] Sonia, P., Mario, N., \& Dilip, R. (2011). Migration and Remittances Household Surveys in SubSaharan africa: Methodological Aspects and Main Findings. World Bank.

[31] Spatafora, N. (2005). Two Current Issues Facing Developing Countries. IMF.

[32] Valpy, F. (2006). Financial Development and Economic Growth: A Critical View. World Economic and Social Survey.

[33] Woodruff, C., \& zenteno, R. (2004). Remittances and Microenterprises in Mexico. IR/PS Working Paper.

[34] World Bank. (2011). Migration and Remittances Fact Book 2011. Washington, DC: The International Bank for Reconstruction and Development (IBRD)/ World Bank.

[35] World Bank. (2013). Migration and Development Brief. World Bank.

[36] Yang, D. (2008). International migration, remittances and household investment: Evidence from Philippines migrants' exchange Rate shocks. The Economic Journal,118.528, 591-630.

\footnotetext{
*Corresponding author.

E-mail address: usmanstrategic@ yahoo.com
} 